\title{
KARAKTERISTIK FISIK, KIMIA DAN SENSORI COOKIES BERBAHAN DASAR TEPUNG KOMPOSIT UWI (Dioscorea alata), KORO GLINDING (Phaseolus lunatus) DAN TEPUNG TERIGU
}

\author{
PHYSICAL, CHEMICAL, AND SENSORY PROPERTIES OF COOKIES MADE FROM \\ COMPOSITE FLOUR YAM (Dioscorea alata), LIMA BEANS (Phaseolus lunatus) AND \\ WHEAT FLOUR
}

Junjung Agung Kurniawan, R. Baskara Katri Anandito, Siswanti

Jurusan Ilmu dan Teknologi Pangan, Fakultas Pertanian, Universitas Sebelas Maret, Surakarta

Email : junjungagungkurniawan.jak@gmail.com

Diserahkan [9 Oktober 2017]; Diterima [10 Desember 2017]; Dipublikasi [26 Februari 2018]

\begin{abstract}
Functional food is processed foods containing one or more food components having certain physiological functions beyond their basic functions, proven not harmful and beneficial to health. Sources of functional food are found in local food as yam and lima beans. Yam and lima beans has a high water content that is not durable, then made a handler that is used as composite flour. Along with the development of snack products such as pastries are increasingly varied, then necessary to develop new products to improve the quality of existing products both in terms of nutritional content and appearance. This research to determine the effect of composite versus formulation on physical, chemical and sensory characteristics of cookies. This research use Completely Randomized Design (CRD) with one factor, that is variations of composite flour with wheat flour $(F 1=0: 100$; $F 2=20: 80 ; F 3=40: 60 ; F 4=60: 40 ; F 5=80: 20)(\% b / b)$. The results of this research indicate that there are significantly different results on physical characteristics (texture), chemistry (moisture content, ash content, carbohydrate content, coarse fiber, calories and antioxidant activity) and sensory (color, taste and overall). The best formulation is $\mathrm{F} 2$ with the compositions (20\% composite flour, fine granulated sugar $30 \mathrm{~g}$, margarine $30 \mathrm{~g}$, butter $7 \mathrm{~g}$, vanilli $0,2 \mathrm{~g}$, egg whites $25 \mathrm{~g}$, egg yolk $7 \mathrm{~g}$, cream of tar-tar 0,4 g, skim milk $14 \mathrm{~g}$, salt 0,8 g, baking soda $0,2 \mathrm{~g}$ ).
\end{abstract}

Keywords : Fungsional Food, Yam, Lima Beans, Composite Flour, Cookies

\begin{abstract}
ABSTRAK
Pangan fungsional adalah pangan olahan yang mengandung satu atau lebih komponen pangan yang mempunyai fungsi fisiologis tertentu di luar fungsi dasarnya, terbukti tidak membahayakan dan bermanfaat bagi kesehatan. Sumber bahan pangan fungsional terdapat pada bahan pangan lokal sepeti uwi dan koro glinding. Uwi dan koro glinding memiliki kandungan air yang tinggi sehingga tidak tahan lama, maka dilakukan penangan yaitu dijadikan tepung komposit. Seiring perkembangan produk makanan ringan seperti kue kering yang semakin banyak variasinya, maka perlu dilakukan pengembangan produk baru untuk meningkatkan mutu produk yang sudah ada baik dari segi kandungan gizi maupun penampakannya. Penelitian ini bertujuan untuk mengetahui pengaruh formulasi tepung komposit terhadap karakteristik fisik, kimia dan sensori cookies. Penelitian ini menggunakan Rancangan Acak Lengkap (RAL) dengan satu faktor yaitu variasi tepung komposit dengan tepung terigu $(\mathrm{F} 1=0: 100 ; \mathrm{F} 2=20: 80 ; \mathrm{F} 3=40: 60 ; \mathrm{F} 4=60: 40 ; \mathrm{F} 5=80: 20)(\% \mathrm{~b} / \mathrm{b})$. Hasil penelitian ini menunjukkan terdapat hasil yang berbeda nyata terhadap karakteristik fisik (tekstur), kimia (kadar air, kadar abu, kadar karbohidrat, serat kasar, total kalori dan aktivitas antioksidan) dan sensori (warna, rasa dan overall). Formulasi terbaik yaitu F2 dengan komposisi (20\% tepung komposit, $80 \%$ tepung terigu, $30 \mathrm{~g}$ gula halus, $30 \mathrm{~g}$ margarin, 7 $\mathrm{g}$ mentega, $0,2 \mathrm{~g}$ vanili, $25 \mathrm{~g}$ putih telur, $7 \mathrm{~g}$ kuning telur, $0,4 \mathrm{~g}$ cream of tar-tar, $14 \mathrm{~g}$ susu skim, $0,8 \mathrm{~g}$ garam, 0,2 g soda kue).
\end{abstract}

Kata Kunci : Pangan fungional, Uwi, Koro Glinding, Tepung Komposit, Cookies

\section{PENDAHULUAN}

Pangan fungsional adalah pangan olahan yang mengandung satu atau lebih komponen pangan yang berdasarkan kajian ilmiah mempunyai fungsi fisiologis tertentu di luar fungsi dasarnya, terbukti tidak membahayakan dan bermanfaat bagi kesehatan (Innova Market Insights, 2013).

Salah satu bahan pangan lokal yang dapat digunakan sebagai pangan fungsional adalah umbi-umbian dan kacang-kacangan. Didukung dengan potensi bahan pangan lokal seperti umbi-umbian yang belum 
optimal pemanfaatannya, inovasi dapat dikembangkan. Salah satu umbi yang potensial adalah uwi. Menurut Hapsari (2014), Uwi (Dioscorea alata) merupakan tanaman pangan lokal yang prospektif sebagai pangan fungsional karena mengandung indeks glikemik yang rendah, serat makanan total yang tinggi, vitamin $\mathrm{C}$ dan mineral, antioksidan, dapat menjaga kesehatan mikroflora usus, dan menghambat pertumbuhan plak aterosklerosis sehingga cocok dikonsumsi semua kalangan. Prospek uwi sebagai pangan fungsional dan bahan diversifikasi pangan dapat dilakukan dengan proses pembuatan tepung yang memiliki kapasitas antioksidan yang baik, selanjutnya dapat digunakan untuk pembuatan beragam produk olahan modern seperti roti, kue kering (cookies), flakes, muffin, mie atau bihun. Selain itu, tepung uwi memiliki kandungan amilosa lebih tinggi sehingga dengan semakin meningkatnya tepung uwi yang digunakan pada kue kering (cookies) maka tekstur semakin rapuh.

Selain umbi-umbian juga ada jenis kacang-kacangan yang memiliki potensi sangat besar menjadi produk pangan apabila ditinjau dari segi gizi yaitu koro glinding. Koro glinding merupakan salah satu jenis koro-koroan yang dapat digunakan sebagai sumber protein nabati dengan kandungan karbohidrat sebesar 70,2\% dan protein $14,8 \%$ (Subagio et.al, 2009). Pada penelitian Johnson et.al, (2013), koro glinding dapat menurunkan glukosa darah pada hewan uji tikus yang diberi alloxan. Sehingga seiring perkembangan produk makanan khususnya makanan ringan atau cemilan kering seperti cookies yang semakin banyak variasinya, maka perlu dilakukan pengembangan produk baru, untuk meningkatkan mutu produk yang sudah ada baik dari segi kandungan gizi maupun penampakannya. Dengan menggunakan tepung komposit uwi dan koro glinding yang disubtitusi menggunakan tepung terigu.

Tepung komposit adalah tepung yang berasal dari beberapa jenis bahan baku yaitu umbi-umbian, kacang-kacangan, atau sereal dengan atau tanpa tepung terigu atau gandum dan digunakan sebagai bahan baku olahan pangan seperti produk bakery dan ekstrusi
(Widowati, 2009). Menurut The African Organisation for Standardisation (2012), syarat minimal kandungan nutrisi tepung komposit yaitu $8,0 \%$ protein, 2,0\% lemak kasar, $1,25 \%$ serat kasar, dan kadar air maksimal 13,5\%. Pembuatan tepung komposit uwi dan koro glinding bertujuan untuk mempermudah dalam pengaplikasian, memperpanjang umur simpan bahan, meningkatkan nilai gizi dan dapat menghilangkan kandungan senyawa berbahaya dalam bahan tersebut. Menurut Prabowo et.al, (2014) uwi memiliki kandungan air yang tinggi yaitu $85 \%$ sehingga dibuat tepung untuk memperpanjang umur simpan. Koro glinding mengandung $\mathrm{HCN}$ yang berbahaya bagi tubuh. Menurut Pramita (2008), menjelaskan bahwa proses pengeringan dapat mempercepat proses penguapan air dan dapat lebih menurunkan kandungan $\mathrm{HCN}$ dan asam fitat sehingga digunakan alternetif lain untuk menghilangkan kandungan $\mathrm{HCN}$ dan memperpanjang umur simpan koro glinding tersebut dengan cara dibuat tepung.

Tepung komposit dianggap berperan penting di negara berkembang karena dapat mengurangi impor tepung terigu dan mendorong penggunaan tanaman lokal berkembang sebagai tepung (Noorfarahzilah et.al, 2014). Menurut APTINDO (2016), data impor gandum Indonesia dari beberapa negara setiap tahunnya terus mengalami peningkatan. Pada tahun 2016 total impor gandum di Indonesia mencapai 8,10 juta ton. Untuk mengatasi masalah tersebut maka sangat penting mencari bahan yang bisa mengganti tepung terigu dengan membuat tepung komposit yang berasal dari produk lokal yaitu tepung komposit dari uwi (Dioscorea alata) dan koro glinding (Phaseolus lunatus). Menurut Utami (2016) pada penelitiannya tentang pengaruh formulasi tepung uwi dan tepung koro glinding terhadap karakteristik fisik, kimia dan fungsional tepung komposit didapatkan formulasi terbaik dengan perbandingan tepung uwi dan tepung koro glinding $85: 15 \% \mathrm{~b} / \mathrm{b}$.

Aplikasi tepung komposit selama ini digunakan untuk pembuatan produk non bakery, salah satunya dijadikan produk mi 
tepung komposit berbahan dasar jagung, ubi kayu, ubi jalar dan terigu (Ratnaningsih et.al, 2010). Selain itu juga diterapkan dalam pembuatan beras analog. Salah satunya yaitu beras analog dari tepung komposit berbahan dasar tepung ubi kelapa dan tepung beras (Adicandra dan Teti, 2016). Sehingga perlu dilakukan pengaplikasian dalam produk lain seperti kue kering (cokies).

Seiring perkembangan peradaban suatu masyarakat, berkembang pula pola hidup termasuk didalamnya pola makan. Hal ini mendorong perubahan gaya hidup masyarakat menuju gaya hidup lebih sehat terutama pola makan. Sejalan dengan itu, fungsi pangan menjadi lebih luas tidak hanya sebagai pemuas selera saja melainkan juga dari segi nilai fungsionalnya. Perkembangan produk makanan khususnya makanan ringan atau cemilan kering seperti cookies semakin banyak variasinya. Cookies atau kue kering merupakan kue yang berkadar air rendah, berukuran kecil dan manis (Suarni, 2009). Sebagai makanan yang disukai masyarakat diperlukan peningkatan nilai gizi dan penganekaragaman produk cookies. Namun, penggunaan tepung komposit akan mempengaruhi karakteristik dari cookies itu sendiri. Oleh karena itu, peneliti ingin mengetahui karakteristik fisik (tekstur), kimia (kadar air, kadar abu, kadar protein, kadar lemak, kadar karbohidrat, total kalori, serat kasar dan antioksidan) dan sensori cookies menggunakan tepung komposit uwi dan koro glinding yang disubtitusi dengan tepung terigu sehingga didapatkan formula cookies yang rendah kalori, tinggi protein, kaya serat dan mengandung antioksidan.

\section{METODE PENELITIAN}

\section{Alat}

Alat yang digunakan dalam penelitian ini terbagi menjadi tiga jenis, yaitu alat yang digunakan untuk produksi tepung uwi dan tepung koro glinding antara lain timbangan, pisau, baskom, cabinet dryer, miller, dan ayakan 80 mesh. Alat yang digunakan dalam pembuatan cookies antara lain timbangan, baskom, mixer, loyang dan oven, serta alat yang digunakan untuk analisa antara lain neraca analitik (Ohaus), spatula, krus, oven (Memmert U 30), penjepit, desikator
(Simax), loyang, kompor listrik, tanur, labu Kjeldahl (Iwaki-Pyrex), mortar, erlenmeyer (Iwaki-Pyrex), penangas air, oven (Memmert), gelas ukur (Iwaki-Pyrex), pompa vakum, spektrofotometer UV-VIS (Shimadzu), gelas beaker (Iwaki-Pyrex), incubator (Memmert), $\mathrm{pH}$ meter, dan waterbath.

\section{Bahan}

Bahan yang digunakan dalam penelitian ini dibagi menjadi tiga jenis, yaitu bahan untuk produksi tepung uwi dan tepung koro glinding antara lain uwi dan koro glinding. Bahan pendukung dalam pembuatan tepung uwi yang digunakan yaitu Na-metabisulfit. Bahan untuk membuat cookies antara lain tepung terigu, gula halus, margarin, mentega, vanili, telur, cream of tartar, susu skim, garam dan soda kue. Serta bahan untuk analisa karakteristik fisik dan kimia cookies antara lain aquades, $\mathrm{HCl} 0,1 \mathrm{~N}$, petroleum eter, $\mathrm{NaOH}$ (Merck) 0,313 N, $\mathrm{H}_{2} \mathrm{SO}_{4}$ (Merck) 0,255 N, etanol 96\%, reagen DPPH (Merck) dan methanol (Merck).

\section{Tahapan Penelitian}

\section{Pembuatan Tepung Uwi}

Tahapan dalam proses pembuatan tepung uwi berdasarkan metode Afidin dkk (2014) dan Prabasini dkk (2013) yaitu dengan cara pengupasan kulit uwi sehingga didapatkan daging uwi. Selanjutnya dilakukan pengirisan setebal 1-2 mm dengan pisau dan diiris tipis. Tujuan dari pengirisan ini adalah untuk mempercepat proses penyerapan Na-metabisulfit pada saat perendaman, selain itu untuk melarutkan lendir pada saat perendaman serta mempercepat penguapan kadar air ketika dikeringkan dalam cabinet dryer. Setelah diiris dilakukan perendaman dalam larutan Na-metabisulfit $0,3 \%$ selama 20 menit. Setelah perendaman Na-metabisulfit kemudian dilakukan pencucian untuk menghindari terjadinya kontaminasi mikroba yang tidak diinginkan yang dapat merusak kandungan gizi tepung uwi. Selanjutnya dilakukan pengeringan dalam cabinet dryer pada suhu $50^{\circ} \mathrm{C}$ selama 24 jam. Uwi yang telah kering kemudian ditepungkan menggunakan alat penepung dan dilakukan 
pengayakan 80 mesh dengan menggunakan mesin pengayak.

\section{Pembuatan Tepung Koro Glinding}

Tahapan dalam proses pembuatan tepung koro glinding berdasarkan metode Rini (2008) dan Gilang dkk, (2013) diawali dengan merendam koro glinding dalam air selama 3 hari dengan pergantian air setiap 12 jam sekali dan perbandingan air dengan koro 3:1. Selanjutnya dilakukan perebusan selama 20 menit (panci tertutup 19 menit, panci terbuka 1 menit). Perebusan dilakukan ketika air mendidih, kemudian dimasukkan koro glinding dan direbus selama 20 menit. Selanjutnya dipisahkan bagian kulit dan biji koro glinding serta dilakukan pembelahan menjadi 2 pada bagian kotiledon. Setelah itu dikeringkan dalam cabiner dryer dengan suhu $60^{\circ} \mathrm{C}$ selama 12 jam. Koro glinding yang sudah kering kemudian ditepungkan menggunakan alat penepung dan dilakukan pengayakan 80 mesh dengan menggunakan mesin pengayak.

\section{Pembuatan Tepung Komposit}

Pembuatan tepung komposit dilakukan dengan mencampurkan tepung uwi dan tepung koro glinding dengan perbandingan 85:15 (Utami, 2016). Formula tepung komposit tersebut dibuat dengan cara mencampurkan tepung uwi dengan tepung koro glinding dalam toples plastik berukuran 250 gram dan dikocok hingga homogen. Pembuatan tepung komposit supaya homogen dilakukan dengan pengompositan sedikit demi sedikit, penuangan dilakukan dengan menuangkan tepung koro glinding terlebih dahulu kemudian tepung uwi karena proporsi tepung koro glinding lebih sedikit dibanding tepung uwi.

\section{Pengujian Tepung Uwi, Tepung Koro Glinding dan Tepung Komposit}

Pengujian tepung uwi, tepung koro glinding dan tepung komposit meliputi kadar air, kadar abu, kadar lemak, kadar protein, kadar karbohidrat, aktivitas antioksidan, kadar serat kasar dan randemen. Hasil Analisa tepung uwi, tepung koro glinding dan tepung komposit dapat dilihat pada Tabel 1; Tabel 2 dan Tabel 3.
Tabel 1 Hasil Analisis Tepung Uwi (Dioscorea alata)

\begin{tabular}{lcc}
\hline \multicolumn{1}{c}{ Analisis } & Teori & Hasil Uji \\
\hline Kadar Air & $7,52 \%$ & $9,1268 \%$ \\
Kadar Abu & $2,36 \% *$ & $4,0075 \%$ \\
Kadar Lemak & $0,17 \% *$ & $1,85 \%$ \\
Kadar Protein & $7,48 \% *$ & $4,74 \%$ \\
Kadar & $82,64 \% *$ & $80,2757 \%$ \\
Karbohidrat & & \\
Serat Kasar & $4,674 \% * *$ & $8,08 \%$ \\
Aktivitas & $25,45 \% * * *$ & $84,2196 \%$ \\
Antioksidan & & \\
Rendemen & $25,632 \%$ & $16,9671 \%$ \\
\hline Ketan
\end{tabular}

Keterangan : Sri Winarti (2013); *Afidin et.al, (2014); **Dina (2010); ***Prasetya dkk (2016)

Tabel 2 Hasil Analisis Tepung Koro Glinding (Phaseolus lunatus)

\begin{tabular}{lcc}
\hline \multicolumn{1}{c}{ Analisis } & Teori & Hasil Uji \\
\hline Kadar Air & $4,1 \%$ & $6,5902 \%$ \\
Kadar Abu & $2,7 \%$ & $1,6445 \%$ \\
Kadar Lemak & $1,6 \%$ & $2,64 \%$ \\
Kadar Protein & $10,9 \%$ & $12,37 \%$ \\
Kadar & $80,7 \%$ & $76,7553 \%$ \\
Karbohidrat & & \\
Serat Kasar & $11 \% *$ & $7,83 \%$ \\
Aktivitas & $7,19 \% * *$ & $44,5969 \%$ \\
Antioksidan & \multicolumn{2}{c}{ 22,1\% } \\
Rendemen & 23,3157\% \\
\hline Keterangan : Nafi & et.al, (2006); *Kay et.al, \\
\multicolumn{2}{c}{ (1979); **Dian Sri (2008) }
\end{tabular}

Tabel 3 Hasil Analisis Tepung Komposit

\begin{tabular}{lcc}
\hline \multicolumn{1}{c}{ Analisis } & $\begin{array}{c}\text { Teori } \\
\text { (Utami, } \\
\text { 2016) }\end{array}$ & Hasil Uji \\
\hline Kadar Air & $8,680 \%$ & $8,9698 \%$ \\
Kadar Abu & $4,054 \%$ & $3,6761 \%$ \\
Kadar Lemak & $0,730 \%$ & $1,29 \%$ \\
Kadar Protein & $10,165 \%$ & $8,39 \%$ \\
Kadar & $76,371 \%$ & $77,6741 \%$ \\
Karbohidrat & & \\
Serat Kasar & $12,859 \% *$ & $4,95 \%$ \\
Aktivitas & $69,650 \%$ & $85,4202 \%$ \\
Antioksidan & & \\
\hline Ketran
\end{tabular}

Keterangan : * serat pangan total

\section{Pembuatan Cookies}

Pembuatan cookies tepung komposit berdasarkan metode Smith (1972) dengan modifikasi, diawali dengan mencampurkan 7 gr mentega, 30 gr margarin, 30 gr gula halus, 
0,8 gr garam dan 0,2 gr vanili dengan kecepatan rendah ke tinggi selama 5-7 menit sampai terbentuk krim yang homogen. Selanjutnya ditambahkan dengan 25 gr putih telur dan 7 gr kuning telur, dimixing dengan kecepatan tinggi selama 3 menit. Setelah tercampur merata kemudian ditambahkan tepung komposit sesuai formula, 14 gr susu skim, 0,2 gr soda kue, dan 0,4 gr cream of tartar dimixing dengan kecepatan rendah selama 3-5 menit. Adonan yang sudah homogen kemudian dicetak dengan ketebalan $5 \mathrm{~mm}$ dan dipanggang dengan suhu $120^{\circ} \mathrm{C}$ selama 20 menit.

\section{Analisis Fisik, Kimia dan Sensori}

Analisis fisik yang dilakukan yaitu tekstur dengan mentode Texture Analyzer (Jensen dkk, 2015). Sedangkan analisis kimia yang dilakukan yaitu kadar air, kadar abu, kadar protein, kadar lemak, kadar karbohidrat menggunakan metode AOAC (2005), total kalori menggunakan metode Bomb Kalorimeter (Mulyaningsih dan Rosida, 2002), serat kasar (Sudarmadji dkk, 2010), aktivitas antioksidan metode DPPH (Zakaria dkk, 2008) dan serat pangan menggunakan metode Asp dan Johanson (1981). Uji sensori dengan uji hedonik Scoring (Setyaningsih dkk, 2010).

\section{Analisis Data}

Semua data hasil analisis sifat fisik, kimia dan sensori dianalisa secara statistik dengan metode One Way Analysis of Variance (ANOVA) untuk mengetahui pengaruh perbedaan variasi pada tingkat kepercayaan 95\%. Kemudian bila ada beda nyata dilanjutkan dengan pengujian Duncan Multiple Range Test (DMRT) pada taraf signifikan $\alpha=0,05$.

\section{HASIL DAN PEMBAHASAN}

\section{Karakteristik Fisik Tekstur Cookies}

Berdasarkan Tabel 4 hasil analisis tekstur dapat dilihat bahwa perbedaan formula penambahan tepung komposit menyebabkan tingkat kekerasan cookies yang berbeda. Hasil uji menunjukkan nilai kekerasan terendah terdapat pada perlakuan penambahan tepung komposit $0 \%$ sebesar 12,12 N. Sedangkan nilai tingkat kekerasan tertinggi terdapat pada perlakuan dengan penambahan tepung komposit sebanyak $80 \%$ sebesar 19,22 N. Pada pengukuran nilai tekstur dapat diketahui bahwa dengan penambahan tepung komposit sebanyak $20 \%$ dapat menyebabkan perbedaan yang nyata terhadap tingkat kekerasan cookies.

Tabel 4 Nilai Tekstur (Kekerasan) Cookies (F max)

\begin{tabular}{cc}
\hline $\begin{array}{c}\text { Formula Cookies } \\
\text { (Tepung Komposit : } \\
\text { Tepung Terigu) }\end{array}$ & F max $(\mathbf{N})$ \\
\hline F1 $(0: 100)$ & $12.12 \pm 0.47^{\mathrm{a}}$ \\
F2 $(20: 80)$ & $15.63 \pm 0.77^{\mathrm{b}}$ \\
F3 $(40: 60)$ & $16.69 \pm 0.08^{\mathrm{bc}}$ \\
F4 $(60: 40)$ & $16.96 \pm 1.94^{\mathrm{bc}}$ \\
F5 $(80: 20)$ & $19.22 \pm 1.98^{\mathrm{c}}$ \\
\hline
\end{tabular}

Keterangan : Huruf yang sama pada kolom yang sama menunjukkan tidak beda nyata pada $\alpha=$ 0.05

Tekstur cookies dipengaruhi oleh kandungan pati dan gluten pada tepung. Tepung komposit uwi dan koro glinding mempunyai kandungan pati sebesar 71,303\% (Utami, 2016). Menurut Williams (2001), gluten pada tepung terigu akan memberikan tekstur yang elastis karena kandungan gluten dan membuat tekstur padat setelah dipanggang. Menurut Handayani (1987), menyatakan bahwa komponen utama yang terdapat dalam tepung yang berpengaruh terhadap tekstur adalah protein. Protein dalam terigu akan membentuk gluten apabila ditambahkan dengan air, yang menyebabkan adonan bersifat elastis dan mampu menahan gas. Apabila jumlah gluten dalam adonan sedikit menyebabkan adonan kurang mampu menahan gas, sehingga pori-pori yang terbentuk dalam adonan juga kecil-kecil. Akibatnya adonan tidak mengembang dengan baik. Sehingga setelah pemanggangan selesai akan menghasilkan produk yang keras. Pada formula penambahan tepung komposit yang berbeda di masing-masing formula dapat menyebabkan kandungan pati dan gluten juga berbeda. Sehingga semakin banyak tepung komposit yang di tambahkan maka kandungan gluten semakin berkurang dan tekstur cookies yang dihasilkan semakin keras. 


\section{Karakteristik Kimia Cookies}

Analisa sifat kimia cookies dilakukan dengan beberapa analisa yang terdiri dari kadar air, kadar abu, kadar lemak, kadar protein, kadar karbohidrat, serat kasar, total kalori, aktivitas antioksidan, dan serat pangan.. Hasil analisa kimia cookies dapat dilihat pada Tabel 5.

\section{Kadar Air}

Berdasarkan hasil uji kadar air cookies diketahui dengan penambahan tepung komposit yang berbeda tiap formula memberikan pengaruh terhadap kadar air cookies. Hasil uji menunjukkan kadar air terendah terdapat pada formula F2 sebesar $3,94 \%$. Sedangkan kadar air tertinggi terdapat pada formula F5 sebesar 5,97\%. Hasil uji ini menunjukkan dengan penambahan tepung komposit sebanyak $20 \%$ memberikan hasil kadar air yang berbeda nyata pada cookies. Berdasarkan SNI 012973-2011 kadar air cookies dianjurkan maksimal 5\%. Formula yang memenuhi syarat SNI cookies yaitu F1, F2 dan F3. Berdasarkan standar UNICEF (2017), kadar air maksimal pada cookies yaitu 4,5\%. Apabila dibandingkan dengan standar internasional UNICEF (2017), formula cookies yang memenuhi yaitu F1 dan F2. Hasil penelitian menunjukkan bahwa semakin banyak tepung komposit yang ditambahkan, maka kadar air semakin tinggi. Semakin tingginya kadar air pada cookies dipengaruhi oleh kandungan amilosa pada tepung komposit sebesar 29,824\% dan amilopektin sebesar 41,480\%. Amilopektin bersifat sukar menyerap air dan sukar melepas air (Utami, 2016).

Berdasarkan hal ini maka kadar air pada cookies akibat perlakuan proporsi tepung komposit, amilopektin yang sifatnya sukar melepas air akan bertambah. Selain itu kadar air pada tepung komposit yang digunakan cukup tinggi yaitu 9,13\%. Menurut Jamaluddin (2014), kandungan pati juga mempengaruhi kadar air produk yang dihasilkan karena adanya dominasi gugus polar hidrofilik $-\mathrm{OH}$ pada keseluruhan rantai polisakarida yang menyebabkan pati dapat menyerap air lebih banyak.

Tabel 5 Karakteristik Kimia Cookies Berbahan Baku Tepung Komposit Uwi, Koro Glinding dan Tepung Terigu

\begin{tabular}{|c|c|c|c|c|c|c|c|}
\hline \multirow{2}{*}{$\begin{array}{c}\text { Sifat Kimia } \\
\text { Cookies } \\
(\%)\end{array}$} & \multirow{2}{*}{$\begin{array}{c}\text { Syarat } \\
\text { SNI (01- } \\
\text { 2973-2011) }\end{array}$} & \multirow[b]{2}{*}{$\begin{array}{c}\text { UNICE } \\
\text { F (2017) }\end{array}$} & \multicolumn{5}{|c|}{ Formula Cookies (Tepung Komposit : Tepung Terigu) } \\
\hline & & & $\begin{array}{c}\text { F1 } \\
(0: 100)\end{array}$ & $\begin{array}{c}\text { F2 } \\
(20: 80)\end{array}$ & $\begin{array}{c}\text { F3 } \\
(40: 60)\end{array}$ & $\begin{array}{c}F 4 \\
(60: 40)\end{array}$ & $\begin{array}{c}\text { F5 } \\
(80: 20)\end{array}$ \\
\hline Kadar Air & Maks. 5 & $\begin{array}{c}\text { Maks. } \\
4,5\end{array}$ & $\begin{array}{l}4,10 \pm \\
0,02^{b}\end{array}$ & $\begin{array}{c}3,49 \pm \\
0,31^{\mathrm{a}}\end{array}$ & $\begin{array}{c}4,80 \pm \\
0,06^{\mathrm{c}}\end{array}$ & $\begin{array}{c}5,11 \pm \\
0,33^{\mathrm{c}}\end{array}$ & $\begin{array}{l}5,97 \pm \\
0,22^{\mathrm{d}}\end{array}$ \\
\hline Kadar Abu & Maks. 1,5 & $\begin{array}{c}\text { Maks. } \\
3,5\end{array}$ & $\begin{array}{c}0,86 \pm \\
0,04^{\mathrm{a}}\end{array}$ & $\begin{array}{c}0,88 \pm \\
0,07^{\mathrm{a}}\end{array}$ & $\begin{array}{c}1,62 \pm \\
0,06^{\mathrm{b}}\end{array}$ & $\begin{array}{c}1,63 \pm \\
0,09^{\mathrm{b}}\end{array}$ & $\begin{array}{c}1,64 \pm \\
0,13^{\mathrm{b}}\end{array}$ \\
\hline $\begin{array}{l}\text { Kadar } \\
\text { Lemak }\end{array}$ & Min. & Min. 15 & $\begin{array}{c}26,34 \pm \\
0,76^{\mathrm{a}}\end{array}$ & $\begin{array}{c}27,50 \pm \\
0,85^{\mathrm{a}}\end{array}$ & $\begin{array}{c}26,35 \pm \\
0,43^{\mathrm{a}}\end{array}$ & $\begin{array}{c}25,65 \pm \\
0,01^{\mathrm{a}}\end{array}$ & $\begin{array}{c}25,59 \pm \\
0,45^{\mathrm{a}}\end{array}$ \\
\hline $\begin{array}{l}\text { Kadar } \\
\text { Protein }\end{array}$ & Min. 5 & Min. 10 & $\begin{array}{c}9,46 \pm \\
0,35^{\mathrm{a}}\end{array}$ & $\begin{array}{c}9,26 \pm \\
0,03^{\mathrm{a}}\end{array}$ & $\begin{array}{c}9,38 \pm \\
0,23^{\mathrm{a}}\end{array}$ & $\begin{array}{c}9,46 \pm \\
0,09^{\mathrm{a}}\end{array}$ & $\begin{array}{c}9,58 \pm \\
0,27^{\mathrm{a}}\end{array}$ \\
\hline $\begin{array}{c}\text { Kadar } \\
\text { Karbohidrat }\end{array}$ & Min. 7 & - & $\begin{array}{c}59.24 \pm \\
1,04^{\mathrm{a}}\end{array}$ & $\begin{array}{c}58,87 \pm \\
0,2^{\mathrm{a}}\end{array}$ & $\begin{array}{c}57,85 \pm \\
0,38^{\mathrm{a}}\end{array}$ & $\begin{array}{c}58,15 \pm \\
0,07^{\mathrm{a}}\end{array}$ & $\begin{array}{c}57,22 \pm \\
0,22^{\mathrm{a}}\end{array}$ \\
\hline Serat Kasar & Maks. 0,5 & $\begin{array}{c}\text { Maks. } \\
2,3\end{array}$ & $\begin{array}{c}0,63 \pm \\
0,03^{\mathrm{b}}\end{array}$ & $\begin{array}{c}0,33 \pm \\
0,02^{\mathrm{a}}\end{array}$ & $\begin{array}{c}0,57 \pm \\
0,06^{\mathrm{b}}\end{array}$ & $\begin{array}{c}1,09 \pm \\
1,75^{\mathrm{c}}\end{array}$ & $\begin{array}{l}1,55 \pm \\
0,09^{d}\end{array}$ \\
\hline Total Kalori & Min. 400 & $\begin{array}{l}\text { Min. } \\
450\end{array}$ & $\begin{array}{c}526,35 \pm \\
30,7^{\mathrm{a}}\end{array}$ & $\begin{array}{c}515,94 \pm \\
8,3^{\mathrm{a}}\end{array}$ & $\begin{array}{c}496,78 \pm \\
6,6^{\mathrm{a}}\end{array}$ & $\begin{array}{c}494,36 \pm \\
7,4^{\mathrm{a}}\end{array}$ & $\begin{array}{c}477,77 \pm \\
7,6^{\mathrm{a}}\end{array}$ \\
\hline $\begin{array}{c}\text { Aktivitas } \\
\text { Antioksidan }\end{array}$ & - & - & $\begin{array}{c}68,78 \pm \\
0,77^{\mathrm{a}} \\
\end{array}$ & $\begin{array}{c}69,65 \pm \\
0,06^{\mathrm{a}} \\
\end{array}$ & $\begin{array}{c}70,05 \pm \\
0,26^{\mathrm{ab}} \\
\end{array}$ & $\begin{array}{c}71,19 \pm \\
0,99 \mathrm{bc} \\
\end{array}$ & $\begin{array}{c}71,60 \pm \\
0,13^{\mathrm{c}} \\
\end{array}$ \\
\hline
\end{tabular}

Keterangan :

Angka dengan huruf yang berbeda pada kolom yang sama menunjukkan beda nyata pada taraf signifikansi $\alpha=0,05$

$\mathrm{F} 1=$ Tepung Komposit (Uwi dan Koro Glinding) : Tepung terigu (0:100)

F2 = Tepung Komposit (Uwi dan Koro Glinding) : Tepung terigu (20:80)

F3 = Tepung Komposit (Uwi dan Koro Glinding) : Tepung terigu (40:60)

F4 = Tepung Komposit (Uwi dan Koro Glinding) : Tepung terigu (60:40)

F5 = Tepung Komposit (Uwi dan Koro Glinding) : Tepung terigu (80:20)

Jurnal Teknologi Hasil Pertanian, Vol. XI, No. 1, Februari 2018 


\section{Kadar Abu}

Hasil uji menunjukkan kadar abu terendah terdapat pada perlakuan kontrol dengan penambahan tepung komposit $0 \%$ sebesar $0,86 \%$. Sedangkan kadar abu tertinggi terdapat pada perlakuan dengan penambahan tepung komposit $80 \%$ sebesar $1,64 \%$. Penambahan kadar abu terlihat meningkat seiring dengan penambahan tepung komposit. Hal ini disebabkan tingginya kandungan abu tepung komposit uwi dan koro glinding yaitu 3,676\%. Cookies berbahan baku terigu berdasarkan SNI 012973-2011 memiliki kadar abu maksimal sebesar $1,5 \%$. Formula yang memenuhi SNI cookies yaitu formula F1 dan F2. Apabila dibandingkan dengan standar cookies menurut UNICEF (2017), kadar abu maksimal pada cookies yaitu sebesar 3,5\%. Kelima formula cookies telah memenuhi standar UNICEF (2017). Berdasarkan hasil penelitian menunjukkan semakin banyak tepung komposit yang ditambahkan maka kadar abu pada cookies semakin tinggi. Menurut Fatkurahman dkk (2012), kadar abu yang semakin tinggi akan berpengaruh terhadap warna cookies yang dihasilkan. Hal ini sesuai dengan hasil uji organoleptik parameter warna yang menunjukkan semakin rendahnya tingkat kesukaan panelis terhadap cookies dengan penambahan tepung komposit yang semakin banyak.

\section{Kadar Lemak}

Hasil uji menunjukkan kadar lemak terendah terdapat pada perlakuan dengan penambahan tepung komposit $80 \%$ sebesar $25,59 \%$. Sedangkan kadar lemak tertinggi terdapat pada perlakuan dengan penambahan tepung komposit $20 \%$ sebesar $27,50 \%$. Berdasarkan hasil uji kadar lemak dapat diketahui bahwa penambahan tepung komposit tidak menyebabkan hasil yang berbeda nyata. Semakin banyak tepung komposit yang ditambahkan maka kadar lemak pada cookies semakin menurun. Hal ini disebabkan tepung komposit yang digunakan memiliki kadar lemak yang rendah yaitu $0,73 \%$ (Utami, 2016). Kadar lemak dari kelima formula cookies tersebut sesuai dengan kadar lemak minimum cookies berbahan dasar tepung terigu yang disyaratkan oleh SNI 01-2973-2011 yaitu minimal 9,5\%. Apabila dibandingkan dengan standar internasional menurut UNICEF (2017), kandungan minimum lemak pada cookies yaitu $15 \%$. Kelima formulasi cookies sudah memenuhi syarat minimum kadar lemak menurut UNICEF (2017). Menurut Harzau dan Teti (2013), semakin tingginya kadar lemak yang terkandung dalam bahan makanan dapat memperbaiki mouth feel dan mempertahankan rasa dari cookies yang dihasilkan.

\section{Kadar Protein}

Kandungan protein cookies sangat dipengaruhi oleh bahan baku yang digunakan dalam pembuatannya. Berdasarkan hasil uji kadar protein cookies didapatkan hasil tidak berbeda nyata pada kelima formula. Kadar protein terendah terdapat pada perlakuan dengan penambahan tepung komposit 20\% sebesar 9,26\%. Sedangkan kadar protein tertinggi terdapat pada perlakuan dengan penambahan tepung komposit $80 \%$ sebesar 9,58\%. Kelima formula cookies telah memenuhi syarat SNI 2973-2011. Apabila dibandingkan dengan UNICEF (2017), kelima formulasi cookies belum dapat memenuhi. Semakin banyak penambahan tepung komposit pada cookies maka kandungan protein yang dihasilkan akan semakin meningkat.

\section{Kadar Karbohidrat}

Hasil uji menunjukkan kadar karbohidrat terendah terdapat pada perlakuan dengan penambahan tepung komposit $80 \%$ sebesar 57,22\%. Sedangkan kadar karbohidrat tertinggi terdapat pada perlakuan dengan penambahan tepung komposit 0\% sebesar 59,24\%. Kelima formula cookies menghasilkan kadar karbohidrat yang tidak berbeda nyata. Dari kelima formula cookies telah memenuhi SNI karena kadar karbohidrat pada hasil penelitian diatas $7 \%$. Pada penelitian Garnis (2016) juga menyatakan semakin banyak jumlah tepung komposit yang ditambahkan maka kandungan karbohidrat semakin menurun. Hal ini sudah sesuai dengan penelitian yang dilakukan, semakin banyak persentase tepung komposit uwi dan koro glinding yang ditambahkan maka kandungan karbohidrat cookies semakin menurun. 


\section{Kadar Serat Kasar}

Hasil uji menunjukkan kadar serat kasar terendah terdapat pada perlakuan dengan penambahan tepung komposit $20 \%$ sebesar $0,33 \%$. Sedangkan kadar lemak tertinggi terdapat pada perlakuan dengan penambahan tepung komposit $80 \%$ sebesar $1,55 \%$. Pada penambahan tepung komposit mencapai $60 \%$ menghasilkan hasil yang berbeda nyata apabila dibandingkan dengan formula cookies $100 \%$ terigu. Formula yang memenuhi SNI 01-2973-2011 tentang batas maksimal serat kasar pada cookies yaitu formula F2 dengan kadar serat kasar 0,33\%. Apabila dibandingkan dengan standar internasional, kelima formula cookies telah memenuhi standar UNICEF (2017). Pada penelitian pendahuluan pengujian tepung komposit uwi dan koro glinding dihasilkan serat kasar sebesar $8,08 \%$. Peningkatan kadar serat kasar ini dipengaruhi oleh subtitusi tepung komposit. Berdasarkan hasil penelitian dapat diketahui bahwa semakin banyak tepung komposit yang ditambahkan menyebabkan kandungan serat kasar semakin meningkat. Menurut (Winarti, 2013) makanan dengan kandungan serat yang tinggi dapat menurunkan berat badan. Hal ini dikarenakan makanan akan tinggal dalam saluran pencernaan dalam waktu yang relatif singkat sehingga adsorbs zat makanan akan berkurang. Selain itu makanan yang mengandung serat akan memberikan rasa kenyang sehingga menurunkan konsumsi makanan.

\section{Total Kalori}

Hasil uji menunjukkan total kalori terendah terdapat pada perlakuan dengan penambahan tepung komposit $80 \%$ sebesar $477,77 \%$. Sedangkan nilai total kalori tertinggi terdapat pada perlakuan dengan penambahan tepung komposit 0\% sebesar $526,35 \%$. Pada kelima formula cookies telah sesuai dengan SNI cookies karena kelima formula cookies memiliki nilai total kalori 477,77 kkal - 526,35 kkal. Apabila dibandingkan dengan standar internasional, kelima formula cookies telah memenuhi syarat minimal kandungan total kalori UNICEF (2017). Menurut Yasinta dkk (2017) semakin banyak tepung komposit yang ditambahkan maka nilai total kalori semakin menurun. Hal ini sesuai dengan penelitian yang dilakukan bahwa penambahan persentase tepung komposit semakin banyak, maka nilai total kalori semakin menurun.

\section{Aktivitas Antioksidan}

Hasil uji menunjukkan aktivitas antioksidan terendah terdapat pada perlakuan dengan penambahan tepung komposit 0\% sebesar 68,78\%. Sedangkan aktivitas antioksidan tertinggi terdapat pada perlakuan dengan penambahan tepung komposit $80 \%$ sebesar $71,60 \%$. Penambahan tepung komposit $60 \%$ menunjukkan hasil yang berbeda nyata apabila dibandingkan dengan cookies $100 \%$ tepung terigu. Berdasarkan hasil uji aktivitas antioksidan dapat diketahui bahwa semakin banyak tepung komposit yang ditambahkan, maka kandungan aktivitas antioksidan semakin meningkat. Pada penelitian pendahuluan tepung komposit uwi dan koro glinding dihasilkan aktivitas antioksidan sebesar 85,42\%. Tingginya aktivitas antioksidan pada cookies tergantung dengan bahan baku yang digunakan dalam pembuatannya.

\section{Karakteristik Sensori Cookies}

Pengujian analisis sensori cookies berbahan baku tepung komposit uwi (Dioscorea alata), koro glinding (Phaseolus lunatus) dan tepung terigu menggunakan lima parameter yaitu warna, aroma, rasa, tekstur dan overallTingkat kesukaan panelis terhadap formulasi cookies dapat dilihat pada Tabel 6.

\section{Warna}

Warna cookies yang timbul dipengaruhi oleh proses pemanggangan yang menyebabkan reaksi maillard sehingga cookies berwarna coklat atau browning. Pada penambahan tepung komposit sebanyak $80 \%$ menghasilkan tingkat kesukaan panelis yang berbeda nyata. Berdasarkan uji sensori parameter warna diketahui bahwa semakin besar variasi penambahan tepung komposit semakin menurun tingkat kesukaan panelis terhadap parameter warna. Hal ini disebabkan karena semakin banyak tepung komposit yang ditambahkan maka cookies cenderung semakin gelap. 
Tabel 6 Nilai Kesukaan Terhadap Cookies Berbahan Baku Tepung Komposit Uwi (Dioscorea alata), Koro Glinding (Phaseolus lunatus) dan Tepung Terigu

\begin{tabular}{cccccc}
\hline $\begin{array}{c}\text { Formula Cookies } \\
\text { (T. Komposit : T. } \\
\text { Terigu) }\end{array}$ & Warna & Aroma & Rasa & Tekstur & Overall \\
\cline { 2 - 6 } & & & & & \\
\hline F1 (0:100) & $3,92 \pm 0,91^{\mathrm{b}}$ & $3,56 \pm 1,00^{\mathrm{a}}$ & $3,36 \pm 0,81^{\mathrm{bc}}$ & $3,56 \pm 0,87^{\mathrm{a}}$ & $3,64 \pm 0,81^{\mathrm{b}}$ \\
F2 (20:80) & $3,84 \pm 1,03^{\mathrm{b}}$ & $4,04 \pm 0,84^{\mathrm{a}}$ & $3,92 \pm 0,91^{\mathrm{c}}$ & $3,88 \pm 1,09^{\mathrm{a}}$ & $4,04 \pm 0,74^{\mathrm{b}}$ \\
F3 (40:60) & $3,52 \pm 0,87^{\mathrm{b}}$ & $3,92 \pm 0,76^{\mathrm{a}}$ & $3,72 \pm 0,89^{\mathrm{bc}}$ & $3,64 \pm 0,86^{\mathrm{a}}$ & $3,84 \pm 0,85^{\mathrm{b}}$ \\
F4 (60:40) & $3,84 \pm 0,94^{\mathrm{b}}$ & $3,76 \pm 1,01^{\mathrm{a}}$ & $3,36 \pm 0,86^{\mathrm{bc}}$ & $3,60 \pm 0,96^{\mathrm{a}}$ & $3,72 \pm 0,98^{\mathrm{b}}$ \\
F5 (80:20) & $2,44 \pm 0,96^{\mathrm{a}}$ & $3,52 \pm 1,19^{\mathrm{a}}$ & $2,96 \pm 0,94^{\mathrm{a}}$ & $3,32 \pm 0,80^{\mathrm{a}}$ & $3,04 \pm 0,89^{\mathrm{a}}$ \\
\hline
\end{tabular}

Keterangan :

Huruf yang sama pada kolom yang sama menunjukkan tidak beda nyata pada $\alpha=0.05$

Skor : 1 = sangat tidak suka, $2=$ tidak suka, $3=$ netral, $4=$ suka, $5=$ sangat suka

Menurut deMan (1997), reaksi dan koro glinding yang berbeda setiap pencoklatan dimulai dengan reaksi gugus formula. Formula dengan penambahan amino, peptide dengan gugus hidroksil tepung komposit paling banyak kurang glikosidik pada gula, kemudian terjadi disukai panelis karena semakin banyak pembentukan polimer nitrogen berwarna tepung komposit yang di tambahkan maka coklat. Reaksi yang berasal dari gugus amino menghasilkan aftertaste pahit. After taste ini berasal dari bahan-bahan yang pahit dapat disebabkan oleh hidrolisis asammengandung protein tinggi seperti tepung asam amino yang terjadi pada reaksi komposit uwi dan koro glinding.

\section{Aroma}

Aroma pada cookies dipengaruhi oleh beberapa bahan yang digunakan antara lain lemak, susu, telur dan tepung yang digunakan. Aroma cookies akan tercium terutama saat cookies dipanggang (Winarno, 2004). Menurut Farida dkk (2008), menyatakan bahwa mentega atau margarin akan memberikan aroma yang harum pada cookies. Berdasarkan hasil uji sensori pada parameter aroma dengan penambahan tepung komposit tidak menghasilkan tingkat kesukaan panelis yang berbeda nyata pada aroma cookies.

\section{Rasa}

Menurut Winarno (2004), rasa merupakan faktor penting untuk menentukan diterima atau tidaknya suatu produk makanan. Berdasarkan hasil uji sensori pada parameter rasa didapatkan hasil semakin banyaknya tepung komposit yang ditambahkan maka tingkat kesukaan panelis akan semakin menurun. Pada penambahan tepung komposit sebanyak $80 \%$ menghasilkan hasil berbeda nyata pada tingkat kesukaan panelis pada parameter rasa. Perbedaan tingkat kesukaan panelis terhadap parameter rasa disebabkan oleh adanya penambahan tepung komposit uwi Maillard saat pembuatan tepung dan pemanggangan cookies. Selain itu, substitusi tepung uwi juga memberikan pengaruh rasa pahit pada cookies. Rasa pahit pada tepung uwi biasanya disebabkan oleh beberapa senyawa kimia seperti fenolik dan alkaloid.

\section{Tekstur}

Tekstur merupakan sensasi tekanan yang dapat diamati dengan melihat dan dirasakan pada waktu digigit, dikunyah, ditelan ataupun perabaan dengan jari (Kartika, 1988). Berdasarkan hasil uji sensori pada parameter tekstur didapatkan hasil yang tidak berbeda nyata pada tingkat kesukaan panelis. Menurut Winarno (2008), tekstur sebuah produk terutama cookies berhubungan dengan kadar air suatu produk tersebut. Kadar air yang tinggi membuat cookies tidak renyah dan teksturnya kurang disukai. Semakin banyak tepung komposit yang ditambahkan maka tekstur cookies semakin padat. Tekstur cookies dipengaruhi oleh kandungan gluten pada tepung. Menurut Manley (2000), gluten merupakan komponen yang sangat penting dalam proses adonan yang akan mempengaruhi tekstur cookies. Polisakarida dapat berfungsi dalam menjaga kekompakan dan kestabilan cookies sehingga apabila semakin banyak pati pada cookies maka tekstur semakin kompak dan 
kerenyahan lebih baik. Menurut Matz (1992), lemak akan melumaskan struktur internal pada adonan untuk mendapatkan tingkat pengembangan yang lebih baik pada saat proses pemanggangan. Lemak pada kuning telur berupa lipoprotein yang terdiri dari $20 \%$ fosfolipid salah satunya lesitin. Lesitin dapat menghasilkan lapisan yang dapat menyatukan cairan antara lemak dan air, yang menyebabkan cookies menjadi lebih renyah. Hal ini sesuai dengan hasil penelitian bahwa semakin banyak tepung komposit uwi dan koro glinding yang ditambahkan maka akan menurunkan tingkat kesukaan panelis. Hal ini disebabkan karena cookies yang dihasilkan memiliki tekstur yang keras karena tidak memiliki gluten di dalamnya.

\section{Overall}

Parameter overall ini menunjukkan kesukaan konsumen terhadap cookies secara keseluruhan. Berdasarkan hasil uji sensori padaparameter overall dapat diketahui bahwa semakin besar variasi penambahan tepung komposit maka cookies semakin kurang disukai panelis. Pada penambahan tepung komposit mencapai $80 \%$ menghasilkan tingkat kesukaan panelis yang berbedanyata terhadap parameter overall. Hal ini disebabkan karena semakin banyak tepung komposit yang ditambahkan mempengaruhi warna dan rasa pada cookies.

\section{Penentuan Formula Terbaik}

Penentuan formula terbaik ini berdasarkan metode Sullivan et.al, (2015). Hasil uji pembobotan atau indeks efektivitas, jumlah nilai hasil $(\mathrm{NH})$ terbesar terdapat pada formula F2 dengan bobot nilai hasil sebesar 0,598. Kemudian formula terbaik kedua yaitu F3 dengan bobot nilai hasil sebesar 0,590. Dengan demikian dapat disimpulkan bahwa formula terbaik cookies berbahan dasar tepung komposit uwi, koro glinding dan tepung terigu adalah $\mathrm{F} 2$ dengan komposisi $20 \%$ tepung komposit dan $80 \%$ tepung terigu. Formula terbaik kedua cookies berbahan dasar tepung komposit uwi, koro glinding dan tepung terigu adalah F3 dengan komposisi $40 \%$ tepung komposit dan $60 \%$ tepung terigu. Kemudian dilakukan uji kadar serat pangan pada kedua formulasi terbaik tersebut.

\section{Persentase Perhitungan \\ Kecukupan Gizi Serat Pangan}

Angka

Perhitungan AKG meliputi kadar serat pangan total, takaran sajian, kalori persajian dan \% AKG serat.

Tabel 7 Informasi Nilai Gizi Serat Pangan Cookies dua Formula Terbaik

\begin{tabular}{lccc}
\hline \multicolumn{1}{c}{ Parameter } & F2 & F3 \\
\hline $\begin{array}{l}\text { Kadar serat } \\
\text { total } \text { (\%bk) }\end{array}$ & pangan & 8,08 & 11,43 \\
$\begin{array}{l}\text { Takaran } \\
\text { (gr/sajian) }\end{array}$ & saji & 30 & 30 \\
$\begin{array}{l}\text { Kalori per } \\
\text { (kkal/sajian) }\end{array}$ & sajian & 154,78 & 149,03 \\
\%AKG serat & & 8,08 & 11,43 \\
\hline
\end{tabular}

Penentuan takaran saji diperlukan untuk mengetahui besarnya sumbangan gizi produk dalam memenuhi angka kecukupan gizi. Berdasarkan Tabel 7 kadar serat pangan total pada formula $\mathrm{F} 2$ yaitu $8,08 \%$ dan $\mathrm{F} 3$ sebesar $11,43 \%$. Dari kedua hasil uji serat pangan total tersebut dapat diklaim sebagai cookies tinggi serat. Berdasarkan BPOM RI Nomor HK 03.1.23.11.11.09909 tahun 2011 menyatakan bahwa sumber bahan pangan dapat diklaim tinggi serat apabila mengandung kadar serat pangan lebih dari 6gram/100gram. Penentuan takaran sajian cookies mengacu pada BPOM (2015), yang menyatakan takaran saji cookies termasuk dalam kategori makanan ringan siap santap berbahan dasar kentang, umbi, serealia, tepung atau pati non-ekstrudat memiliki rentang takaran saji sebesar 20-40 gram. Berdasarkan peraturan BPOM (2015), maka ditetapkan takaran sajian cookies sebesar 30 gram/sajian. Cookies terpilih F2 memiliki kontribusi serat pangan sebesar 8,08\% AKG dan F3 sebesar $11,43 \%$ AKG, dengan kebutuhan serat pangan harian sebesar 30gr/orang/hari (BPOM. 2016). Menurut peraturan kepala BPOM RI nomor 9 tahun 2016 tentang Acuan Label Gizi, rata-rata kecukupan energi masyarakat Indonesia sebesar $2150 \mathrm{kkal} /$ orang/hari. Berdasarkan peraturan tersebut maka cookies tepung komposit uwi, koro glinding dan tepung terigu ini mengandung $154,78 \mathrm{kkal} / \mathrm{sajian}$ dan 149,03 kkal/sajian. Sehingga formula F2 dan F3 dapat memenuhi kebutuhan 
kecukupan energi harian sebesar 7,20\% dan $6,93 \%$.

\section{KESIMPULAN}

Berdasarkan penelitian yang telah dilakukan, dapat diambil kesilmpulan sebagai berikut:

1. Formulasi cookies menyebabkan pengaruh yang berbeda nyata terhadap karakteristik fisik (tekstur), kimia (kadar air, kadar abu, kadar karbohidrat, serat kasar, total kalori dan aktivitas antioksidan) dan sensori (warna, rasa dan overall).

2. Formula cookies dua terbaik berdasarkan karakteristik fisik, kimia dan sensori adalah F2 (20\% tepung komposit, 80\% tepung terigu, 30 gram gula halus, 30 gram margarin, 7 gram mentega, 0,2 gram vanili, 25 gram putih telur, 7 gram kuning telur, 0,4 gram cream of tar-tar, 14 gram susu skim, 0,8 gram garam, 0,2 gram soda kue) dan F3 (40\% tepung komposit, 60\% tepung terigu, 30 gram gula halus, 30 gram margarin, 7 gram mentega, 0,2 gram vanili, 25 gram putih telur, 7 gram kuning telur, 0,4 gram cream of tar-tar, 14 gram susu skim, 0,8 gram garam, 0,2 gram soda kue).

3. Formula cookies $\mathrm{F} 2$ mengandung $\%$ AKG serat pangan sebesar $8,08 \%$; kalori per sajian sebesar 154,78 kkal/sajian; dan memenuhi kebutuhan kecukupan energi harian sebesar 7,20\%. Formula F3 mengandung \% AKG serat pangan sebesar 11,43\%; kalori per sajian sebesar $149,03 \mathrm{kkal} / \mathrm{sajian}$ dan dapat memenuhi kebutuhan kecukupan energi harian sebesar $6,93 \%$.

\section{DAFTAR PUSTAKA}

Adicandra, Rizki Mukti., dan T. Estiasih. 2016. Beras Analog dari Ubi Kelapa Putih (Dioscorea alata L.): Kajian Pustaka. Jurnal Pangan dan Agroindustri 4(1): 383-390.

Afidin, Muhammad Nur., Y. Hendrawan dan R.Yulianingsih. 2014. Analisis Sifat Fisik dan Kimia pada Pembuatan Tepung Umbi Uwi Ungu (Dioscorea alata), Uwi Kuning (Dioscorea alata) dan Uwi Putih (Dioscorea alata. Jurnal Keteknikan Pertanian Tropis dan Biosistem 2(3): 297-303.
AOAC. 2005. Official Methods of Analysis of Association of Official Analitycal Chemist. AOAC, Inc. Arlington, Virginia.

APTINDO. 2016. Industri Tepung Terigu Nasional Indonesia. Asosiasi Produsen Tepung Terigu. Jakarta.

Asp, N.G., Johansson, C.G., Halmer, H. and Siljestrom, M. 1983. Rapid Enzymatic Assay of Insoluble Dietary Fiber. $J$. Agr. Food Chem, (31):476-482.

Badan Pengawas Obat dan Makanan. 2011. Pengawasan Klaim dalam Label dan Iklan Pangan Olahan Nomor HK. 03.1.23.11.11.09909. http://www.pom.go.id./15/09/2011.

Badan Pengawas Obat dan Makanan. 2016. Peraturan Kepala Badan Pengawas Obat dan Makanan Republik Indonesia Nomor 9 Tahun 2016 tentang Acuan Label Gizi Pangan Olahan. Jakarta.

Badan Pengawas Obatdan Makanan. 2015. Pengawasan Takaran Saji Pangan Olahan. Jakarta.

Badan Standarisasi Nasional. 2011. Syarat Mutu Cookies SNI 2973-2011.

deMan, M John. 1997. Kimia Makanan. Bandung : ITB

Faridah, Anni, dkk. 2008. Patisari Jilid 2 Untuk Smk.Direktorat Pembinaan Sekolah Menengah Kejuruan. Jakarta.

Fatkurahman, R., Atmaka, W., dan Basito. 2012. Karakteristik Sensori dan Sifat Fisikokimia Cookies Dengan Substitusi Bekatul Beras Hitam (Oryza sativa L.) dan Tepung Jagung (Zea mays L.). Jurnal Teknosains Pangan 1(1) : 48-57.

Garnis, Mariasina. 2016. Karakteristik Cookies Kaya Serat Berbahan Baku Campuran Mocaf, Tepung Tempe Telur, Tepung Kacang Hijau Dan Tepung Pisang Nangka. Skripsi. Universitas Sebelas Maret Surakarta.

Gilang, Retna., Dian, Rachmawanti Affandi., dan Dwi, Ishartani. 2013. Karakteristik Fisik dan Kimia Tepung Koro Pedang (Canavalia enviromis) dengan Variasi Perlakuan Pendahuluan. Jurnal Teknosains Pangan 2(3).

Handayani, Tituk Sri Swasti. 1987. Pencarian Metode Tekstur Cookies yang Menggunakan Campuran Terigu dan 
Maizena dengan Penetrometer. Skripsi. Fakultas Teknologi Pertanian. UGM. Yogyakarta

Hapsari, Ratri Tri. 2014. Prospek Uwi Sebagai Pangan Fungsional dan Bahan Diversifikasi Pangan. E-jurnal Litbang Pertanian.

Harzau, Hazizah., dan T. Estiasih. 2013. Karakteristik Cookies Umbi Inferior Uwi Putih (Kajian Proporsi Tepung Uwi : Pati Jagung dan Penambahan Margarin). Jurnal Pangan dan agroindustri 1 (1): 138-147.

Innova, Market Insights. 2013. Functional Foods: The True Fuctional of Foods. Foodreview. May 2014.

Jamaluddin., Robert, Molenaar., dan Deddie, Tooy. 2014. Kajian Isotermi Sorpsi Air dan Fraksi Air Terikat Kue Pia Kacang Hijau Asal Kota Gorontalo. Jurnal Ilmu dan Teknologi Pangan 2(1).

Jensen, Sidsel., Leif H., Skibsted., Ulla Kidmose., Anette K., and Thybo. 2014. Addition of Cassava Flours in Breadmaking: Sensory and Textural Evaluation. Food Science and Technology 60(1): 292-299.

Johnson, O. R., Segilola, L. I., Ogundele, O. M. Akiniayo, C. O., and Seriki, Samuel. 2013. Biochemical Evaluation of Lima Beans (Phaseolus lunatus) in Alloxan Induced Diabetic Rats. ARPN Journal of Agricultural and Biological Science 8(4): 302-309.

Kartika, Bambang. 1988. Pedoman Uji Indrawi Bahan Pangan. PAU Pangan dan Gizi. Universitas Gajah Mada.

Manley, D.J.R. (2001). Biscuit, Cracker, and Cookie Recipes For The Food Industry. Woodhead Publishing Limited, Abington. England.

Matz, S. A. 1972. Bakery Technology and Engineering. Second Edition. The Avi Publishing Co, Inc, Westport, Connecticut.

Mulyaningsih, Yeni dan Jernih Rosida. 2002. Membandingkan Hasil Analisis Energi Total Menggunakan Bom Kalorimeter dengan Hasil Analisis Proksimat. Temu Teknis Fungsional Non Penelitis 2002.
Nafi, A., Tri, Susanto., dan Achmad, Subagio. 2006. Pengembangan Tepung Kaya Protein (TKP)) dari Koro Komak (Lablab purpureus L Sweet) dan Koro Kratok (Phaseolus lunatus). Jurnal Teknologi dan Industri Pangan17(3):. 159-165.

Noorfarahzilah, M., Lee J.S., Sharifudin M.S., Mohd Fadzelly A.B., and Hasmadi M. 2014. Application of Composite Flour in Development of Food Product. International Food Research Journal 21(6): 2061-2074.

Prabowo, A. Y., Teti, Estiasih., dan Indria, Purwantiningrum. 2014. Umbi Gembili (Dioscorea esculenta L.) sebagai Bahan Pangan Mengandung Senyawa Bioaktif : Kajian Pustaka. Jurnal Pangan dan Agroindustri 2(3): 129135.

Pramita, Dian Sri. 2008. Pengaruh Teknis Pemanasan Terhadap Kadar asam Fitat dan Aktivitas Antioksidan Koro Benguk (Mucuna pruriens), Koro Glinding (Phaseolus lunatus) dan Koro Pedang (Canavalia ensiformis). Skripsi. Universitas Sebelas Maret.

Prasetya., M. Wahyu Agung., T. Estiasih., dan N. Ida Panca Nugrahiru. 2016. Potensi Tepung Ubi Kelapa Ungu dan Kuning (Dioscorea alata L.) sebagai Bahan Pangan Mengandung Senyawa Bioaktif : Kajian Pustaka. Jurnal Pangan dan Agroindustri 4(2): 468473.

Ratnaningsih, Asep W. Permana., dan Nur, Richana. 2010. Pembuatan Tepung Komposit Jagung, Ubi Kayu, Ubi Jalar dan Terigu (Lokal dan Impor) untuk Produksi Mi. Prosiding Pekan serealia Nasional. ISBN: 978-979-8940-29-3.

Rini, Ari Widyas. 2008. Pengaruh Penambahan Tepung Koro Glinding (Phaseolus lunatus) Terhadap Sifat Kimia dan Organoleptik Mi Basah dengan Bahan Baku Tepung Terigu, Tepung Ubi Jalar Ungu (Ipomoea batatas). Skripsi. Universitas Sebelas Maret.

Setyaningsih, D., Apriyantono A., dan Sari MP. 2010. Analisis Sensori untuk 
Industri Pangan dan Agro. IPB Press, Bogor.

Smith. 1972. Biscuit, Crackers and Cookies. Applied Science Publisher Ltd, London 1.

Suarni. 2009. Prospek Pemanfaatan Tepung Jagung untuk Kue Kering (Cookies). Jurnal Litbang Pertanian 28(2).

Subagio, A., W. S. Windrati., Y. Witono., dan A. Nafi. 2009. Development Of Non Oilseed Legumes as Source of Protein to Strengthen Food Security in Marginal Areas. Universitas Jember.

Sudarmadji S, dkk. 2010. Prosedur Analisa untuk Bahan Makanan dan Pertanian. Liberty. Yogyakarta.

Sullivan, William G., Elin M. Wicks dan C. Patrick Koelling. 2015. Engineering Economy Sixteenth Edition. Pearson Education Ltd. Upper Saddle River.

The African Organisation for Standardisation. 2012. Cassava Wheat Composite Flour-Specification. Edict ofGoverment. CD-ARS842 Fisrt Edition.

Unicef. 2017. International Standards High Energy Biscuits. A Fleet.

Utami, Rohma Fitri. 2016. Pengaruh Formulasi Tepung Uwi (Dioscorea alata) dan Koro Glinding (Phaseolus lunatus) Terhadap Karakteristik Fisik, Kimia dan Fungsional Tepung Komposit. Skripsi. Universitas Sebelas Maret.

Williams dan Margareth. 2001. Food Experimental Perspective, Fourth Edition. Prentice Hall, New Jersey.

Winarno, F. G. 2004. Kimia Pangan dan Gizi. Gramedia Pustaka Utama. Jakarta.

Winarno, F. G. 2008. Kimia Pangan dan Gizi. Mbrio Press. Bogor.

Winarti, Sri., dan E. Adi Saputro. 2013. Karakteristik Tepung Prebiotik Umbi Uwi (Dioscorea spp). Jurnal Teknik Kimia 8(1): 17-21.

Yasinta, Ulfi N.A., B. Dwiloka., dan Nurwantoro.2017. Pengaruh Subtitusi Tepung Terigu dengan Tepung Pisang terhadap Sifat Fisikokimia dan Organoleptik Cookies. Jurnal Aplikasi Teknologi Pangan 6 (3).
Zakaria, Z., Aziz, R., Lachimanan, Y. L., Sreenivasan, S., and Rathinam, X., 2008, Antioxidant activity of Coleus blumei, Orthosiphon stamnieus, Ocimum basilicum and Mentha arvensis from Lamiaceae family, J.Nat. Eng. Sci., (2): 93-95. 